\title{
A REGCM4.5 REGIONÁLIS KLÍMAMODELL TESZTELÉSE: A HIDROSZTATIKUS ÉS NEM-HIDROSZTATIKUS KÖZELÍTÉS SZEREPE KÜLÖNBÖZŐ CSAPADÉKSÉMÁK ALKALMAZÁSA MELLETT
}

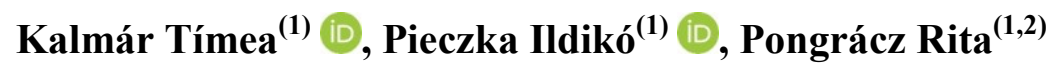 \\ ${ }^{(1)}$ ELTE Meteorológiai Tanszék, 1117 Budapest, Pázmány Péter sétány 1/A \\ ${ }^{(2)}$ ELTE TTK Kiválósági Központ, 2462 Martonvásár, Brunszvik u. 2. \\ e-mail:kalmartimea@caesar.elte.hu,pieczka@nimbus.elte.hu,prita@nimbus.elte.hu
}

\section{Bevezetés}

Az éghajlati rendszer müködésének minél pontosabb megértéséhez elengedhetetlen a klímamodellek alkalmazása és folyamatos fejlesztése. A modellfejlesztések egyik célja a múltban detektált éghajlati viszonyok, változások minél pontosabb rekonstruálása. Ha ez elfogadható mértékben sikerül, akkor következő lépésként a klímamodellek felhasználásával becsülhetjük az éghajlat jövőben várható változásait is. Napjainkban a regionális modellek már néhány kmes horizontális felbontással is rendelkezhetnek, amely sokszor nem-hidrosztatikus közelítést igényel. Ahhoz, hogy a modell megfelelően müködjön, szükséges a modelldinamika módosítása, valamint a modell rácsfelbontásánál finomabb térskálájú folyamatok fizikai parametrizációinak további fejlesztése.

Vizsgálataink során a RegCM4.5 regionális klímamodellel végeztünk modellfuttatásokat 10 km-es horizontális felbontás mellett a Kárpát-medencére az 1981-1990 időszakra. A kezdeti- és peremfeltételeket az ERA-Interim reanalízis adatbázis $\left(0,75^{\circ}\right.$-os horizontális felbontással) szolgáltatta. A választásunk azért esett a RegCM4.5 modellverzióra, mert a korábbi verziókhoz képest a hidrosztatikus $(\mathrm{H})$ közelítés mellett már nem-hidrosztatikus $(\mathrm{NH})$ dinamikával is futtatható. E modellverzió másik nagyobb újítása, hogy a nem-konvektív eredetü felhőzet és csapadék kezelésére egy új csapadéksémát is beépítettek. A vizsgálatok során egyrészt a modelldinamikát, másrészt a nagytérségü csapadéksémákat teszteltük különböző beállítások mellett.

\section{A RegCM4.5 regionális klímamodell}

A RegCM regionális klímamodellt a trieszti központú ICTP ${ }^{1}$ fejleszti (Elguindi et al., 2014). A RegCM4.5 verzió már nem-hidrosztatikus dinamikával is rendelkezik, amelynek alapja az MM5 mezoskálájú modell nem-hidrosztatikus verziója. A korábbi verziókhoz képest a másik lényeges fejlesztés, hogy egy új parametrizációs sémát építettek a modellbe, ami a réteges felhőzet mikrofizikájának és a csapadékképződésnek a részletesebb leírására szolgál (Nogherotto et al., 2016). A modell által használt régebbi séma, az ún. $\operatorname{SUBEX}^{2}$ (Pal et al., 2000) a nem-konvektív eredetü felhőzet és csapadék kezelésére szolgál. A séma Sundqvist et al. (1989) munkája alapján figyelembe veszi a felhőzet rácscellákon belüli változását úgy, hogy kapcsolatot teremt a rácscella átlagos relatív nedvességtartalma, a felhővel való borítottság, valamint a felhővíz között. Az új NogTom ${ }^{3}$ felhő-mikrofizikai sémát az ECMWF's IFS ${ }^{4}$ alapján dolgozták ki (Tiedtke, 1993; Nogherotto et al., 2016). Az új séma öt prognosztikai egyenletet old meg vízgőz, felhővíz, eső, jég és hó keverési arányra (Elguindi et al., 2014).

\footnotetext{
${ }^{1}$ International Centre for Theoretical Physics

${ }^{2}$ SUBgrid EXplicit moisture scheme

${ }^{3}$ NOGherotto TOMpkins cloud-microphysics scheme

${ }^{4}$ ECMWF Integrated Forecast System
} 
Összehasonlítva a korábbi sémával, ez az újítás a vegyes halmazállapotú felhőzet, a felhő mikrofizikájának és a csapadéknak fizikailag reálisabb reprezentációját teszi lehetővé.

\section{Elvégzett szimulációk és validáció}

E tanulmányban bemutatandó vizsgálataink során a RegCM4.5 regionális klímamodellel végeztünk modellfuttatásokat $10 \mathrm{~km}$-es horizontális felbontás mellett a Kárpát-medencére (lefedő rácspontok száma $120 \times 216$, a vertikális szintek száma 23), a teljes integrálási idő 1979.12.01-1990.12.31, melyből az első évet felpörgési időként tekintettük, s így az értékelésböl természetesen kihagytuk. A kezdeti- és peremfeltételeket az ERA-Interim reanalízis adatbázis $\left(0,75^{\circ}\right.$-os horizontális felbontás mellett) szolgáltatta. A szimulációk főbb beállításai az 1. táblázatban láthatók.

1. táblázat: Az elvégzett szimulációk főbb jellemzői.

\begin{tabular}{|c|c|c|c|c|c|}
\hline & \begin{tabular}{|l|l|} 
H_SUBEX & H_SUB4.3 \\
\end{tabular} & NH_SUBEX & H_NogTom & NH_NogTom & NH_NogTom_NC \\
\hline Földfelszíni almodell & \multicolumn{5}{|c|}{ BATS (Dickinson et al., 1993) } \\
\hline Közelítés & $\mathrm{H}$ & NH & $\mathrm{H}$ & & $\mathrm{NH}$ \\
\hline $\begin{array}{l}\text { Nagytérségü } \\
\text { csapadékséma }\end{array}$ & \multicolumn{2}{|c|}{ SUBEX (Pal et al., 2000) } & \multicolumn{3}{|c|}{ NogTom (Nogherotto et al., 2016) } \\
\hline $\begin{array}{l}\text { Konvektív csapadék- } \\
\text { séma (szárazföld) }\end{array}$ & \multicolumn{4}{|c|}{ Grell séma (1993) FC (Fritsch és Chappell, 1980) lezárással } & nincs \\
\hline $\begin{array}{l}\text { Konvektív csapadék- } \\
\text { séma (vízfelszín) }\end{array}$ & \multicolumn{5}{|c|}{ MIT-Emanuel (Emanuel, 1991) } \\
\hline
\end{tabular}

Megjegyzendő, hogy a SUBEX sémában Torma et al. (2011) módosították a 2. táblázatban feltüntetett paraméterek értékét: az autokonverziós együtthatót a felére csökkentették, az esöcsepp párolgási együtthatóját két nagyságrenddel növelték, ugyanakkor az akkréciós (cseppbefogási) együtthatót a felére csökkentették. Mindezek a szimulált csapadék felülbecslésének csökkentésére szolgáltak és bekerültek a RegCM4.3-ba (H_SUB4.3), azonban a RegCM4.5ben visszaállították a régi értékekre (H_SUBEX). Az NH_NogTom_NC szimuláció esetén a konvektív parametrizációt kapcsoltuk ki a szárazföld felett. A vízfelszín felett számítás esetén technikai okok miatt hagytuk meg a konvektív sémát.

2. táblázat: A H_SUBEX és a H_SUB4.3 szimuláció közti különbség.

\begin{tabular}{|l|c|c|}
\hline & H_SUB4.3 & H_SUBEX \\
\hline Autokonverziós együttható & 0,00025 & 0,0005 \\
\hline Esőcsepp párolgási együttható & $1,0 \cdot 10^{-3}\left(\mathrm{~kg} \cdot \mathrm{m}^{-2} \cdot \mathrm{s}^{-1}\right)^{-1 / 2} \cdot \mathrm{s}^{-1}$ & $1,0 \cdot 10^{-5}\left(\mathrm{~kg} \cdot \mathrm{m}^{-2} \cdot \mathrm{s}^{-1}\right)^{-1 / 2} \cdot \mathrm{s}^{-1}$ \\
\hline Eső́csepp akkréciós együttható & $3 \mathrm{~m}^{3} \cdot \mathrm{kg}^{-1} \cdot \mathrm{s}^{-1}$ & $6 \mathrm{~m}^{3} \cdot \mathrm{kg}^{-1} \cdot \mathrm{s}^{-1}$ \\
\hline
\end{tabular}

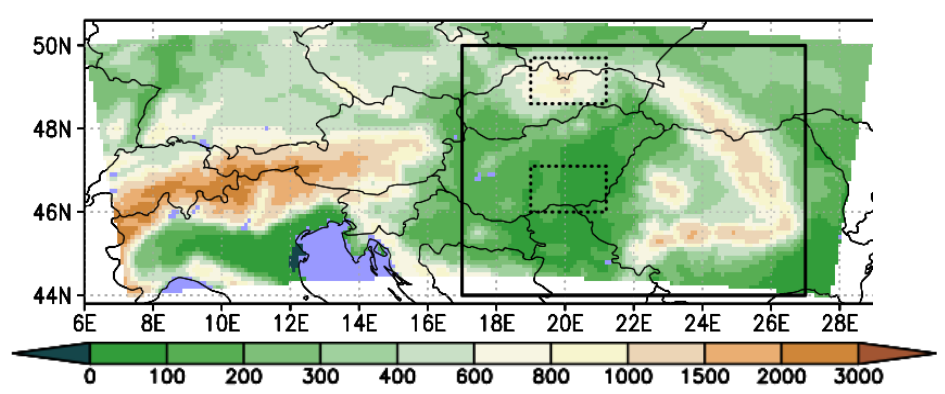

1. ábra: A RegCM teljes integrálási tartománya és a validációhoz használt CarpatClim adatbázis által lefedett terület domborzata (fekete téglalap). A vizsgálatok során kiválasztott két kisebb terület: Tátra térsége (felső pontozott vonallal jelölt téglalap) és az Alföld egy kisebb része (alsó pontozott vonallal jelölt téglalap). 
A validációhoz a CarpatClim adatbázist (Szalai et al., 2013) választottuk, mivel Magyarország területére jelenleg ez a publikusan elérhetö legrészletesebb, legfinomabb $-0,1^{\circ}$-os horizontális felbontású adatbázis. A CarpatClim adatbázis idősorai közül a 2 m-es középhőmérsékletet $\left({ }^{\circ} \mathrm{C}\right)$, illetve a napi csapadékösszeget $(\mathrm{mm})$ használtuk fel. A meteorológiai változók orográfiától való jelentős függése miatt az egész területre vonatkozó átlagértékek mellett két kisebb - domborzatát tekintve jelentősen eltérő - régiót választottunk ki, és így az egyes vizsgálatok során területi átlagokat képeztünk az Alföld déli részére és a Tátra környékére (1. ábra).

\section{Eredmények}

A modelleredmények validációs értékelése során a havi és évszakos középhőmérsékletet, valamint a havi és évszakos átlagos csapadékösszeget vetettük össze a CarpatClim adatbázisból származtatott referencia adatokkal. Ebben a tanulmányban az egyes futtatásokból kapott átlagos hibamezőket és az átlagos évi menet reprodukálását vizsgáljuk először a hőmérsékletre, majd a csapadékra vonatkozóan. A csapadék esetén külön hangsúlyt fektettünk a konvektív csapadék részletesebb vizsgálatára.

\section{Hömérséklet}

A 2. ábrán az átlagos évszakos hibamezők láthatók a CarpatClim adatbázishoz képest az 1981-1990-es időszakra. Mindegyik modellbeállítás esetén szembetűnő a nyári jelentősebb ( $3{ }^{\circ} \mathrm{C}$ körüli) felülbecslés, ami a korábbi modellverziókra (RegCM3: Torma et al., 2011; RegCM4.3: Pieczka et al., 2017), illetve más modellekre (Hagemann et al., 2001) is jellemző. Az okok felderítése érdekében több kutatás is folyt: Machenhauer et al. (1998) a meghajtó modell és az RCM közötti dinamikai leskálázás okozta hibára, míg Hagemann et al. (2001) a szárazföldi területek fizikai parametrizációira vezette vissza a nyári felülbecslést. Seneviratne et al. (2006) a talajnedvesség-tartalommal és annak inicializálásával hozta kapcsolatba a megfigyelésekhez képest átlagosan melegebb és szárazabb nyarakat. A RegCM-mel kapott korábbi tanszéki eredményekhez (Torma et al., 2011; Pieczka et al., 2017) képest újdonság, hogy a Balaton területén ősszel és télen viszonylag nagy $\left(2-3{ }^{\circ} \mathrm{C}-\mathrm{os}\right)$ pozitív hiba jelenik meg. Ez egyrészt amiatt történt, hogy a CarpatClim adatbázis homogenizált adatsor, a vízfelszín felett nem tartalmaz méréseket, csak a parton, emiatt a Balaton nem jelenik meg benne. Másrészt a RegCM4.5 a korábbi verziókhoz képest más interpolációs eljárást alkalmaz a felszín előállításakor, melynek eredményeképpen a Balaton itt már mint vízfelszín jelenik meg, ahol a modell a szárazföldhöz képest más parametrizációs sémákat és konstansokat alkalmaz a számításokban, amelyek hatással lehetnek a hőmérséklet alakulására is. A téli időszakban a legkisebb hiba összességében a H_NogTom futtatásnál tapasztalható, míg a legnagyobb hiba az NH_SUBEX-nél látható. A Kárpátok vonulatainál minden futásnál kismértékü, jellemzően inkább negatív hiba tapasztalható. Habár tavasszal az Alföld területére a H_NogTom futtatás adta a legjobb becslést, a Kárpátok vonulataira és Erdély területére negatív hiba jellemezte.

Az átlagos évszakos hibák mellett a havi átlaghőmérséklet éven belüli menetét is meghatároztuk a két kiválasztott területre. Az alföldi és a Tátra környéki (3. ábra) területre a modellek az éven belüli menetet visszaadták, azonban a nyári félévben felülbecsülték az átlagos havi középhömérsékletet. Jól látszik, hogy az alföldi területen nagyobb hömérsékleti értékek adódtak és a különbségek is nagyobbak a modellszimulációk és a CarpatClim között, mint a Tátra térségében. A legnagyobb felülbecslés júliusban jellemző: az alföldi területen átlagosan $3{ }^{\circ} \mathrm{C}$ a modellszimulációk hibája, míg a hegyvidéken $2{ }^{\circ} \mathrm{C}$ körüli. 
Kalmár T., Pieczka I., Pongrácz R.: A RegCM4.5 regionális klímamodell tesztelése: a hidrosztatikus és nem-hidrosztatikus közelítés szerepe különböző csapadéksémák alkalmazása mellett
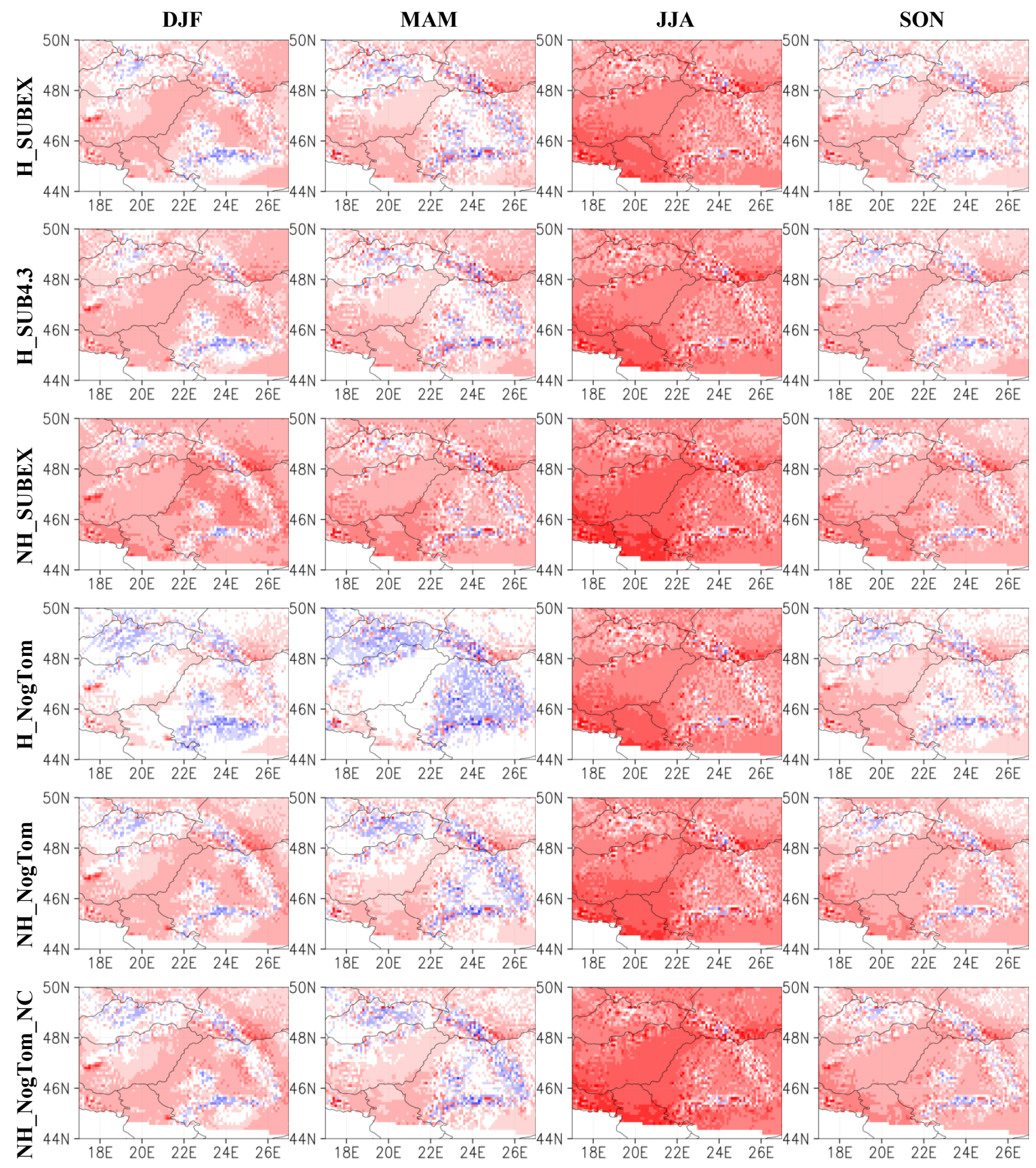

Hőmérsékleti hiba $\left[{ }^{\circ} \mathrm{C}\right]$

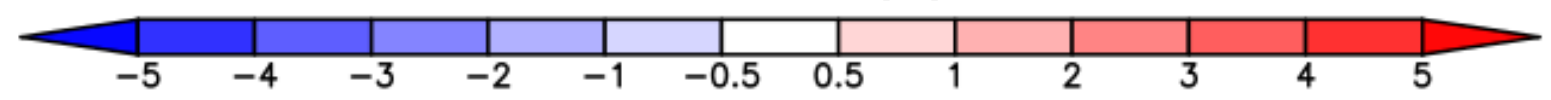

2. ábra: Az egyes modellszimulációk átlagos évszakos hőmérsékleti eltérése a CarpatClim adatbázistól (1981-1990). 


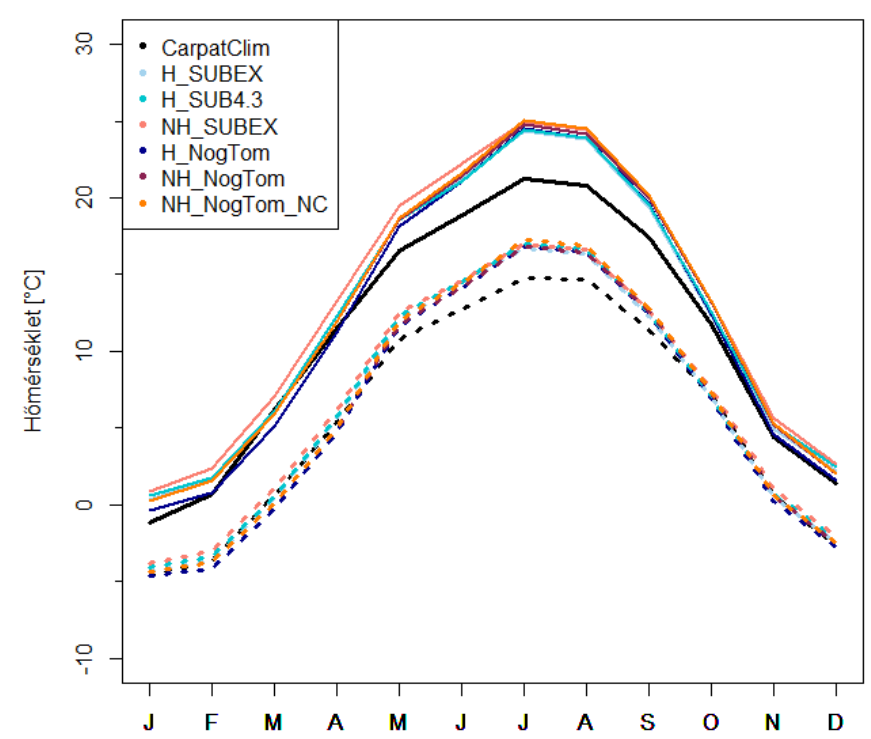

3. ábra: A havi átlaghőmérséklet éven belüli eloszlása a két kiválasztott területre.

Az Alföldre vonatkozó értékek folytonos vonallal jelennek meg, míg a Tátra térségére pontozott vonallal. Referencia adatbázis: CarpatClim (1981-1990).

\section{Csapadék}

A 4. ábrán láthatók az egyes szimulációkhoz tartozó átlagos évszakos relatív hibamezők. A hőmérséklethez viszonyítva a csapadék esetén jóval nagyobb különbségek vannak az egyes szimulációk között. A csapadékmezők térbeli struktúrájára jellemző, hogy a hegyvidéki területeken a szimulációk mindegyik évszakban felülbecslik a CarpatClim referencia értékeit. Az is jól látható, hogy a H_SUB4.3 futtatás csapadékhibái kisebbek a hegyvidéki területen, mint a SUBEX sémával készített futásé (H_SUBEX). Ezek alapján érdemes visszatérni azokra a változtatásokra a SUBEX séma alkalmazása esetén, amelyek a 2. táblázatban szerepelnek. A legnagyobb negatív hiba - ami az Alföld területén jelent meg - mindegyik évszakban az NH_NogTom_NC-nél tapasztalható: a síkvidékeken 50\% vagy annál nagyobb alulbecslés figyelhető meg minden évszakban, de nyáron a legszembetűnőbb. Ez az eredmény természetesen nem meglepő: a nagy hibát a konvektív csapadékséma kikapcsolása okozza, amikor csak a modelldinamika által és a nagytérségü csapadékséma által számolt csapadék jelenik meg, mely $10 \mathrm{~km}$-es felbontás mellett a megfigyeltnél jóval kevesebb.

A legkisebb hibák ősszel és télen fordulnak elő az egész terület átlagát tekintve, ami abból adódik, hogy a hegységekben előforduló nagy pozitív hibák és az alacsonyabb síkvidéki területek negatív hibái kiejtik egymást. A tavaszi hibamezők esetén látható, hogy a H_SUBEX szinte mindenhol felülbecsülte a csapadékmennyiséget, míg a nem-hidrosztatikus dinamikát alkalmazó szimulációk a Kárpátokban felülbecslik, az alföldi területeken pedig alulbecslik a csapadékot. A korábbi tanszéki vizsgálatokkal (Pieczka et al., 2017) összevetve - ahol negatív értékek föleg az északi területeken jelentek meg - itt az alföldi területeken látható negatív hiba.

Összességében elmondható, hogy várakozásainknak megfelelően az NH_NogTom_NC futtatás adta a legpontatlanabb becsléseket minden évszakra: az alföldi területeken alulbecsülte, míg a hegyvidéki területeken jelentősen felülbecsülte a csapadékot. A hibamezők ezen általános struktúrája - különböző mértékben - más futtatások esetén is megfigyelhető. A legpontosabb eredményeket a H_NogTom, illetve a H_SUB4.3 szimuláció produkálta mind a négy évszakot tekintve, tehát a hidrosztatikus közelítés a $10 \mathrm{~km}$-es horizontális felbontás alkalmazásával kisebb hibákat eredményezett, mint a nem-hidrosztatikus közelítés. 

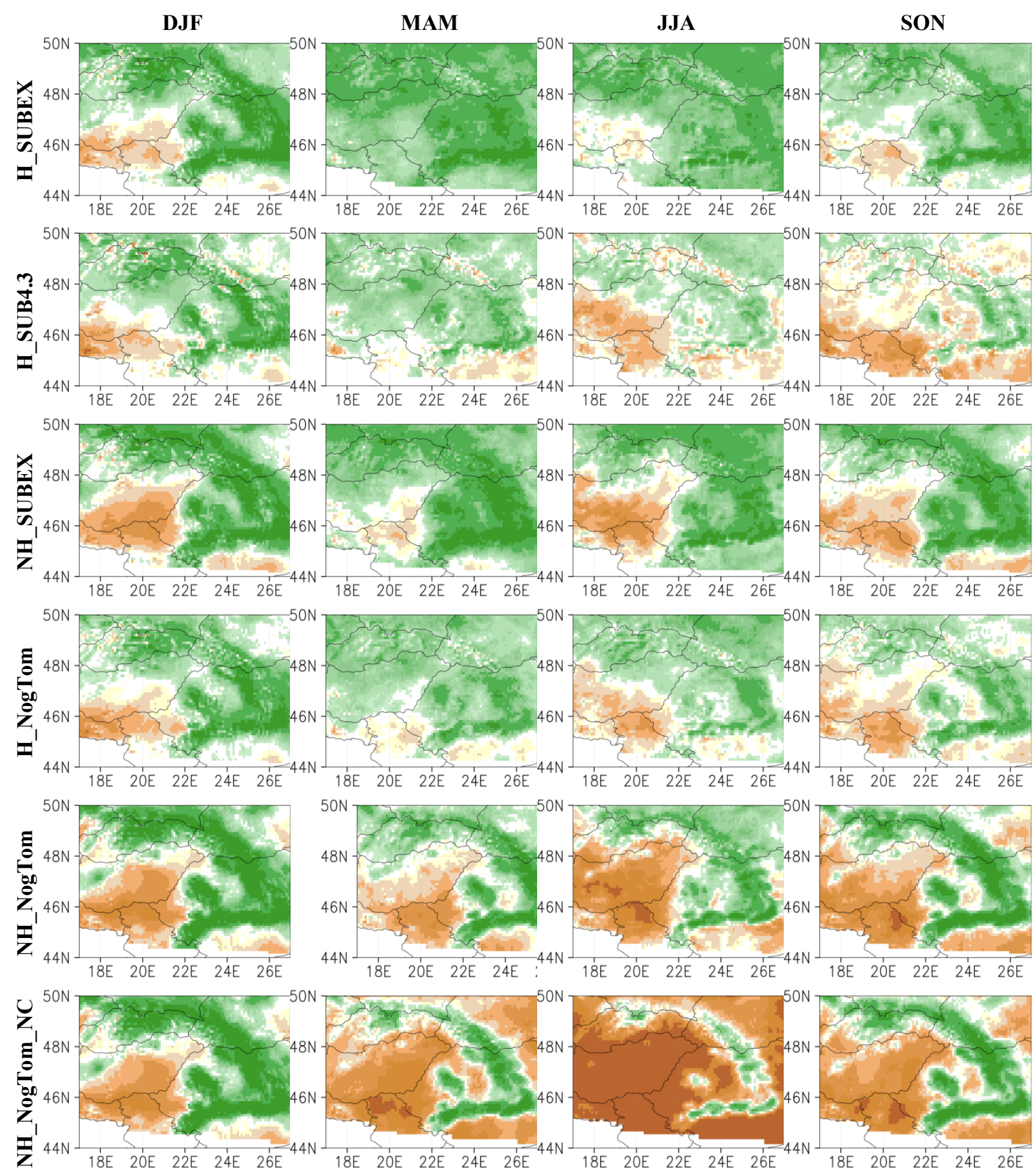

Csapadék hiba [\%]

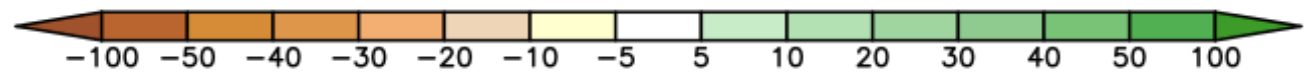

4. ábra: Az egyes modellszimulációk átlagos évszakos csapadék-eltérése a CarpatClim adatbázistól (1981-1990).

Az átlagos havi csapadékösszegek éven belüli eloszlása látható az 5. ábrán az alföldi és a Tátra környéki területre átlagolva. Jól látszik, hogy az Alföldön és a Tátrában a szimulált csapadék éves menete hasonló a CarpatClim adatbázis adataiból számított éven belüli eloszláshoz. Ennek ellenére a hibamezőkből kapott eredményeknek megfelelően az alföldi terü- 
leten általánosságban tekintve a csapadék alulbecslése jellemző, míg a Tátrában inkább felülbecslés jelenik meg.

Az Alföldre vonatkozólag az NH_NogTom és az NH_NogTom_NC becsli legnagyobb mértékben alul az átlagos havi csapadékösszegeket a nyári félévben. (Az NH_NogTom_NC közel 30 mm-rel, míg az NH_NogTom 15 mm-rel.) A késő tavaszi, kora nyári időszakban a H_SUBEX futtatás becsüli felül legjobban a megfigyeléseket. A csapadék éves menetét az itt bemutatott hat szimuláció közül a H_NogTom adta vissza a legpontosabban az Alföldre.

A Tátra térségére a szimulációk felülbecslése jellemző az egész év során. A legkisebb különbség a szimulált csapadékösszeg és a referencia adatok között a H_SUB4.3 futtatás esetén figyelhető meg. Télen az NH_NogTom_NC adja a legnagyobb értékeket, míg nyáron az NH_SUBEX és a H_SUBEX.

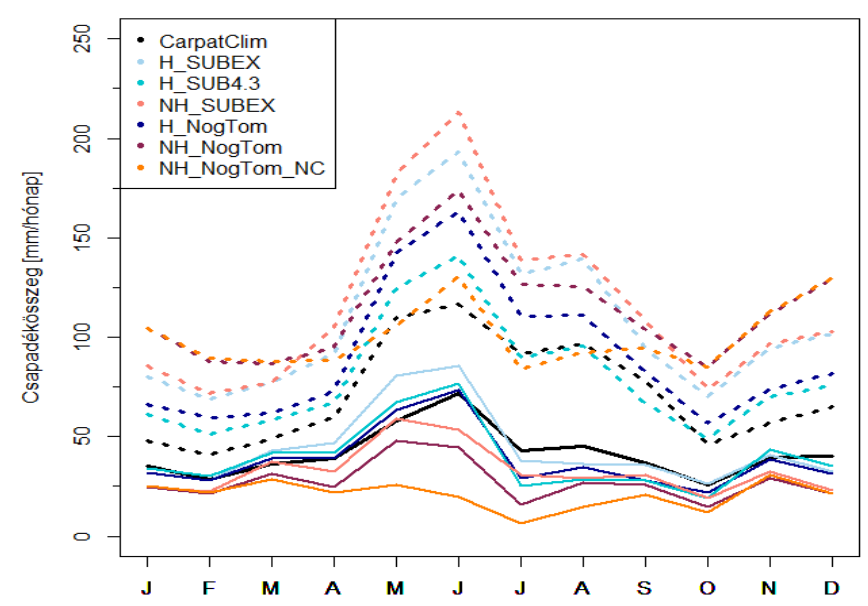

5. ábra: Az átlagos havi csapadékösszegek éven belüli eloszlása a két kiválasztott területre. Az Alföldre vonatkozó értékek folytonos vonallal jelennek meg, míg a Tátra térségére pontozott vonallal. Referencia adatbázis: CarpatClim (1981-1990).

Taylor-diagramon (Taylor, 2001) is összehasonlítottuk a szimulációk csapadékbecsléseit (6. ábra). A színek a különböző beállításokat reprezentálják, míg a szimbólumok az adott térségre (Alföld, Tátra és a teljes CarpatClim kivágat) vonatkoznak. Annál pontosabb a szimuláció eredménye, minél közelebb helyezkedik el a megfigyeléshez tartozó, üres körrel jelölt ponthoz. A diagramon jól látszik, hogy az NH_NogTom_NC beállítás mellett a legpontatlanabb a csapadékbecslés: ilyenkor a legnagyobbak a szórások és a legkisebbek a korrelációs együtthatók. A megfigyelésekhez az új mikrofizikai sémát alkalmazó szimulációk (H_NogTom, NH_NogTom) vannak a legközelebb, ezeknek egyértelmüen kisebb a szórásuk. A teljes kivágatot tekintve a SUBEX sémát tartalmazó szimulációkra erősebb korreláció adódott a CarpatClim referencia adataival, mint a NogTom felhő-mikrofizikai sémával készült futtatások esetén.

A csapadék esetén a kapott szimulációs hibák indokolták a konvektív és nem-konvektív eredetü csapadék külön-külön történő értékelését. Ebben a tanulmányban a konvektív csapadékot vizsgáljuk részletesen. Az alkalmazott nem-hidrosztatikus közelítésü beállításokban a vertikális irányú gyorsulásokat számolja a modell, de emellett az általánosan megadott konvektív parametrizációt is bekapcsolva hagytuk. Ez alól csak az NH_NogTom_NC szimuláció kivétel, amely esetén csak a szárazföld felett használatos Grell sémát kapcsoltuk ki, míg a tengerek felett továbbra is használtuk az MIT-Emanuel sémát. A konvektív csapadékra vonatkozóan a CarpatClim adatbázis nem tartalmaz adatokat, így az eddigiekkel ellentétben nem hibatérképeket mutatunk be, továbbá a teljes integrálási tartományra készültek a 7. ábra térképei. 


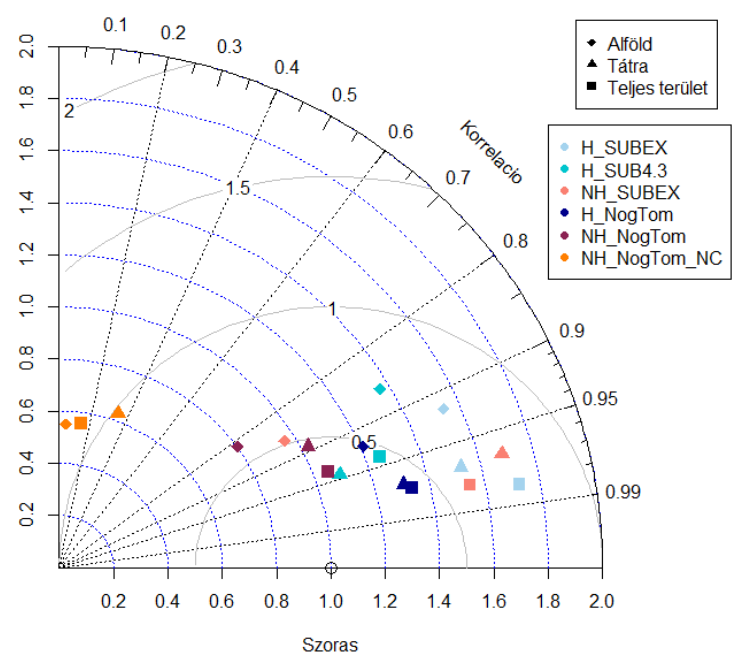

6. ábra: Az átlagos havi csapadékösszeg időbeli menetének Taylor-diagramja (1981-1990).

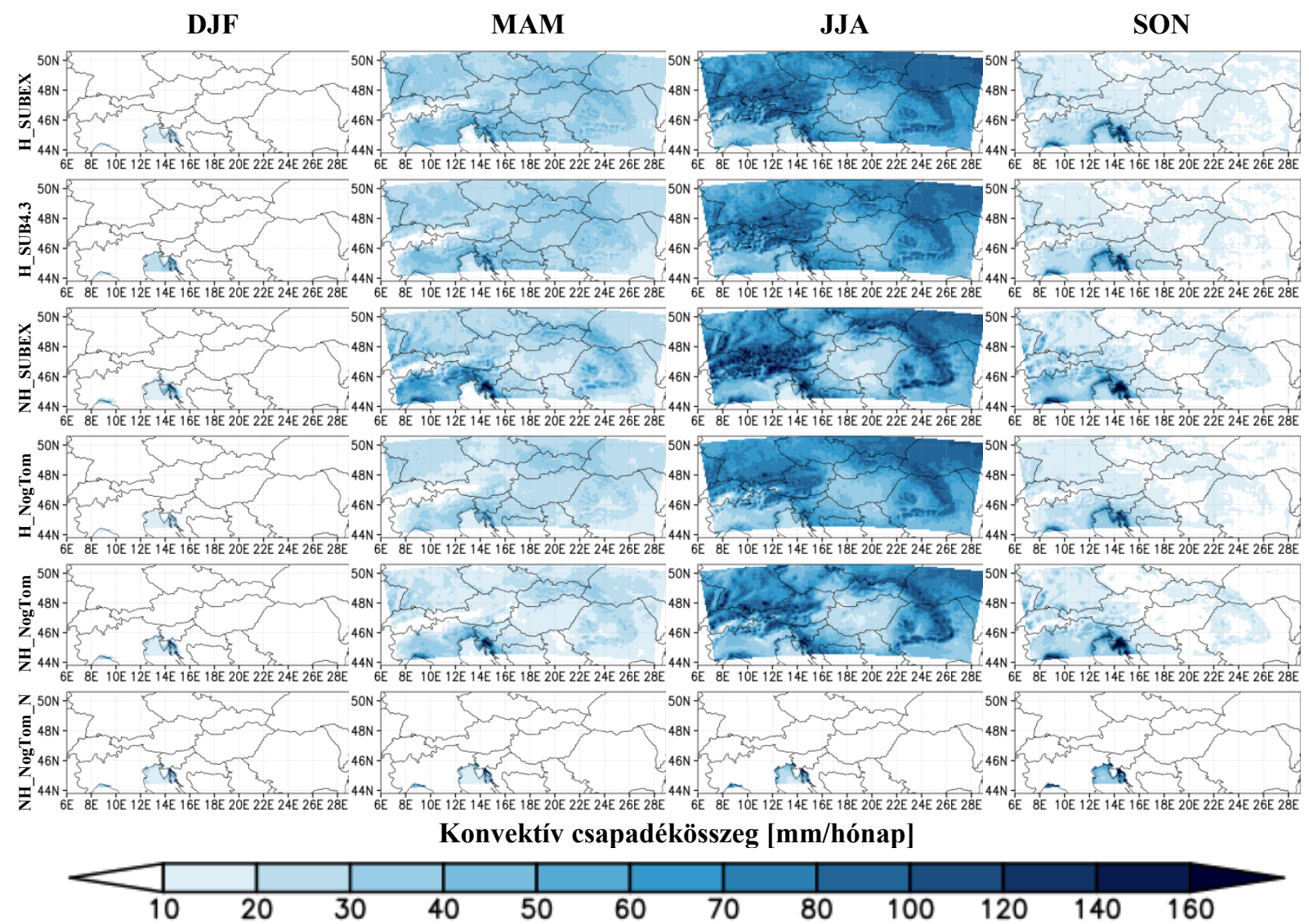

7. ábra: Az egyes modellszimulációk átlagos évszakos konvektív csapadékösszege (mm/hónap) (1981-1990).

Jól látszik, hogy várakozásainknak megfelelően télen (és ősszel) a legkisebb a konvektív csapadék mennyisége. A konvekcióhoz szükséges energetikai feltételek hiánya miatt télen elhanyagolható a konvektív csapadék. Ez alól kivételt képez a Dinári-hegység nyugati oldala, ahol a téli félévben is viszonylag sok konvektív csapadék hullik. Ez egyrészt a nyugati áramlásoknak való kitettségnek, másrészt a Földközi-tengerhez való közelségnek és az orográfiának köszönhető: a nyugatias áramlásokkal érkező nedves légtömegeket a hegység a téli hónapokban is felemelkedésre kényszeríti. A kapott eredmények további oka a víz- 
felszínek felett alkalmazott MIT-Emanuel séma, ami hatással van ezekre a területekre. Tavasszal már a síkvidéken is megjelenik jelentősebb konvektív csapadék, mely alól kivétel csupán az utolsó szimuláció, ahol továbbra is csak a Dinári-hegység környékén okoz konvektív csapadékot az MIT-Emanuel séma. Mindez nem jelenti azt, hogy a szimuláció nem számol konvektív csapadékot, csak az ún. 'prc' változóba a parametrizáció által számolt csapadék kerül bele; a modelldinamika általi pedig nem. A szimulációk közül az NH_SUBEX eredményezi a legtöbb csapadékot tavasszal. A legmagasabb értékek - ahogyan az ebben a régióban megszokott - minden esetben nyáron fordulnak elő mindegyik szimuláció esetén. Nyáron a legnagyobb értékek az Alpok vonulatainál tapasztalhatók: a nem-hidrosztatikus szimulációk esetén sokkal markánsabb a konvektív csapadék mennyisége, mint a hidrosztatikus közelítéssel készített futtatásokban.

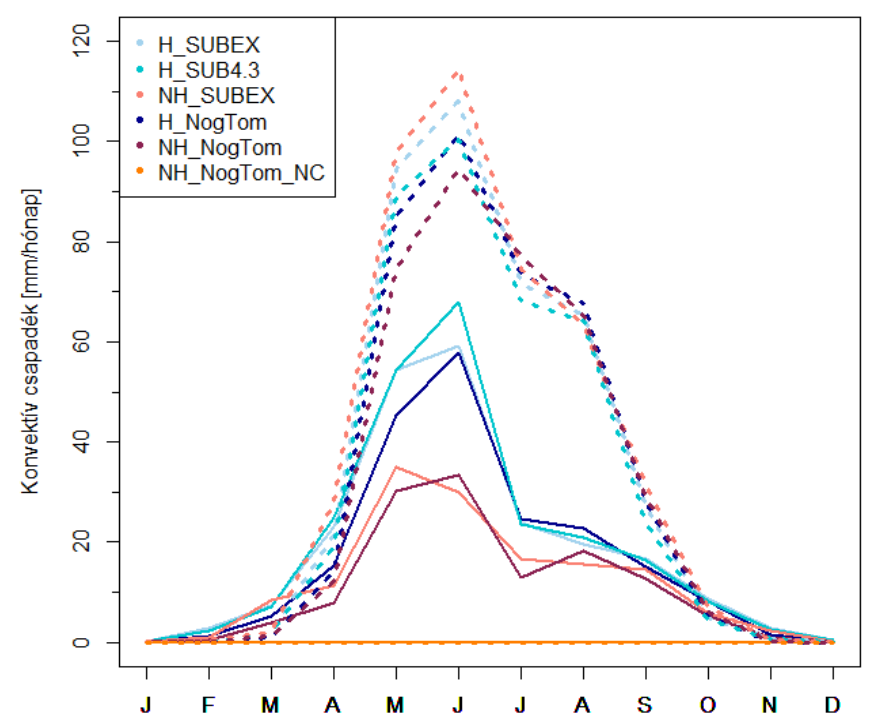

8. ábra: Az átlagos havi konvektív csapadékösszeg éven belüli eloszlása a két kiválasztott területre. Az Alföldre vonatkozó értékek folytonos vonallal jelennek meg, míg a Tátra térségére pontozott vonallal. (1981-1990).

A 8. ábra az Alföldre és a Tátra térségére vonatkozó átlagos havi konvektív csapadékösszegeket hasonlítja össze. A grafikonon jól látszik, hogy várakozásainknak megfelelően a Tátra térségében általában magasabb értékek fordultak elő, mint az Alföldön.

Az Alföldön a nem-hidrosztatikus közelítéssel készült futásoknál (NH_SUBEX, NH_NogTom) a csapadékeloszlás időbeli menetében kisebb éven belüli különbségek jelentkeznek, mint a hidrosztatikus futások esetén. A késő tavaszi, kora nyári időszakban viszont a hidrosztatikus közelítéssel készített szimulációk akár $50 \mathrm{~mm}$-rel is meghaladták a nemhidrosztatikus közelítést alkalmazó szimulációk átlagos konvektív csapadékösszegét.

A hegyvidéki területnél a nyári félév legnagyobb értékei az NH_SUBEX futtatásnál fordultak elö, míg a második legnagyobb értéket a H_SUBEX eredményezte. Ezek alapján elmondható, hogy a régi SUBEX séma a hegyvidéki területeken jobban felülbecsli a csapadékot, mint a NogTom új mikrofizikai séma. A módosított SUBEX séma viszont nagyságrendileg hasonló értékeket eredményezett, mint a NogTom séma.

\section{Összefoglalás}

Munkánk során a RegCM4.5 regionális klímamodellel végeztünk modellfuttatásokat $10 \mathrm{~km}$ es horizontális felbontás mellett a Kárpát-medencére az 1981-1990 időszakra. A futtatások során egyrészt a hidrosztatikus és nem-hidrosztatikus dinamikát hasonlítottuk össze, másrészt 
a modellben rendelkezésre álló két nagytérségű csapadéksémát. Az eredményeket a CarpatClim adatbázissal hasonlítottuk össze a hömérséklet és a csapadék esetén. Ezen kívül az egyes futtatások által szimulált konvektív csapadékot is elemeztük.

A kapott eredmények alapján a modell a nyári hőmérsékletet jelentős mértékben $\left(3^{\circ} \mathrm{C}\right)$ felülbecsülte. Az új NogTom mikrofizikai sémával csak tavasszal javultak az eredmények.

A csapadék esetén a korábbi eredményekhez (Pieczka et al., 2017) képest különbségek a hegyvidéki és síkvidéki területek között figyelhetők meg. A hegységekben a nem-hidrosztatikus közelítéssel készített szimulációk jobban felülbecsülték a csapadékot, kivételt képez az NH_NogTom_NC futtatás, ahol a speciális beállítások hatására a legnagyobb negatív hibák fordultak elö.

A konvektív csapadék vizsgálatakor - mivel a CarpatClim adatbázis nem tartalmazza ezt a változót - a teljes kivágatra készítettünk térképet, illetve a kiválasztott régiókra az éves menetet reprezentáló diagramot. A konvektív csapadék esetén a szimulációk nyáron a hegységekben (Alpok, Kárpátok) adták a nagyobb értékeket.

Összességében elmondható, hogy a korábbi eredményekhez (RegCM4.3) képest a csapadék esetén javulás tapasztalható az új (RegCM4.5) modellverzióval készített szimulációkban. Megállapítható továbbá az is, hogy a hidrosztatikus közelítéssel készített szimuláció az új NogTom mikrofizikai sémával adta a pontosabb eredményeket. Ebből arra következtethetünk, hogy a $10 \mathrm{~km}$-es felbontás még nem elég finom ahhoz, hogy a modelldinamika expliciten számolja a csapadékot.

További terveink között szerepel - többek között - az alapértelmezett felszíni séma $\left(\right.$ BATS $^{5}$ ) helyett a CLM ${ }^{6}$ alkalmazása, illetve a legújabb modellverzió (RegCM4.7) használata.

\section{Köszönetnyilvánítás}

Kutatásainkat támogatta a Nemzeti Kutatási, Fejlesztési és Innovációs Alap K-120605 és K129162 számú projektje, a Széchenyi 2020 program, Magyarország Kormánya és az Európai Regionális Fejlesztési Alap az AgroMo kutatási projekt (GINOP-2.3.2-15-2016-00028) keretében, valamint az Emberi Erőforrások Minisztériuma az ELTE Felsőoktatási Intézményi Kiválósági Program (1783-3/2018/FEKUTSRAT) keretében. A CARPATCLIM Adatbázis előállítását az Európai Közösség támogatta a JRC intézeten keresztül kiírt kutatási program keretében.

\section{Hivatkozások}

Dickinson, R.E., Errico, R.M., Giorgi, F., Bates, G.T., 1989: A regional climate model for the western United States. Clim. change, 15(3): 383-422. https://doi.org/10.1007/BF00240465

Elguindi, N., Bi, X., Giorgi, F., Nagarajan, B., Pal, J., Solmon, F., Rauscher, S., Zakey, A., O'Brien, T., Nogherotto, R., Giuliani, G., 2014: Regional climatic model RegCM Reference Manual version 4.5. ITCP, Trieste, Italy. 37p.

Emanuel, K.A., 1991: A scheme for representing cumulus convection in large-scale models. $J$. Atmospheric Sci, 48(21), 2313-2329. https://doi.org/10.1175/15200469(1991)048<2313:ASFRCC $>2.0 . \mathrm{CO} ; 2$

Fritsch, J.M., Chappell, C.F., 1980: Numerical prediction of convectively driven mesoscale pressure systems. Part II. Mesoscale model. J. Atmospheric Sci., 37(8): 1734-1762. https://doi.org/10.1175/1520-0469(1980)037<1734:NPOCDM>2.0.CO;2

\footnotetext{
${ }^{5}$ Biosphere-Atmosphere Transfer Scheme

${ }^{6}$ Coupled Land Model
} 
Grell, G.A., 1993: Prognostic evaluation of assumptions used by cumulus parameterizations. Mon. Weather Rev., 121(3): 764-787. https://doi.org/10.1175/15200493(1993) $121<0764:$ PEOAUB $>2.0 . \mathrm{CO} ; 2$

Hagemann, S., Botzet, M., Machenhauer, B., 2001: The summer drying problem over southeastern Europe: sensitivity of the limited area model HIRHAM4 to improvements in physical parameterization and resolution. Physics and Chemistry of the Earth. Part B: Hydrology, Oceans and Atmosphere, 26(5-6): 391-396. https://doi.org/10.1016/S14641909(01)00024-7

Machenhauer, B., Windelband, M., Botzet, M., Christensen, JH., Déqué, M., Jones, RG., Ruti, PM., Visconti, G., 1998: Validation and analysis of regional present-day climate and climate change simulations over Europe. Max Planck Intitut für Meteorologie Report, 275, MPI, Hamburg, Germany.

Nogherotto, R., Tompkins, A.M., Giuliani, G., Coppola, E., Giorgi, F., 2016: Numerical framework and performance of the new multiple-phase cloud microphysics scheme in RegCM4. 5: precipitation, cloud microphysics, and cloud radiative effects. Geosci. Model Dev., 9(7): 2533-2547. https://doi.org/10.5194/gmd-9-2533-2016

Pal, J.S., Small, E.E., Eltahir, EA., 2000: Simulation of regional-scale water and energy budgets: Representation of subgrid cloud and precipitation processes within RegCM. $J$. Geophys. Res.: Atmospheres, 105(D24), 29579-29594. https://doi.org/10.1029/2000JD900415

Pieczka, I., Pongrácz, R., André, K.S., Kelemen, F.D., Bartholy, J., 2017: Sensitivity analysis of different parameterization schemes using RegCM4. 3 for the Carpathian region. Theor. Appl. Climatol., 130(3-4), 1175-1188. https://doi.org/10.1007/s00704-016-1941-4

Seneviratne, S.I., Lüthi, D., Litschi, M., Schär, C., 2006: Land-atmosphere coupling and climate change in Europe. Nature, 443(7108): 205. https://doi.org/10.1038/nature05095

Szalai, S., Auer, I., Hiebl, J., Milkovich, J., Radim, T., Stepanek, P., Zahradnicek, P., Bihari, Z., Lakatos, M., Szentimrey, T., Limanowka, D., Kilar, P., Cheval, S., Deak, Gy., Mihic, D., Antolovic, I., Mihajlovic, V., Nejedlik, P., Stastny, P., Mikulova, K., Nabyvanets, I., Skyryk, O., Krakovskaya, S., Vogt, J., Antofie, T., Spinoni, J., 2013: Climate of the Greater Carpathian Region. Final Technical Report. www.carpatclim-eu.org

Sundqvist, H., Berge, E., Kristjansson, J.E., 1989: Condensation and cloud parameterization studies with a mesoscale numerical weather prediction model. Mon. Weather Rev., 117(8): 1641-1657. https://doi.org/10.1175/1520-0493(1989)117<1641:CACPSW>2.0.CO;2

Taylor, K.E., 2001: Summarizing multiple aspects of model performance in a single diagram. J. Geophys. Res.: Atmospheres, 106(D7): 7183-7192.

https://doi.org/10.1029/2000JD900719

Tiedtke, M., 1993: Representation of clouds in large-scale models. Mon. Weather Rev., 121(11): 3040-3061.

https://doi.org/10.1175/1520-0493(1993)121<3040:ROCILS >2.0.CO;2

Torma, C., Coppola, E., Giorgi, F., Bartholy, J., Pongrácz, R., 2011: Validation of a highresolution version of the regional climate model RegCM3 over the Carpathian basin. $J$. Hydrometeor., 12(1): 84-100. https://doi.org/10.1175/2010JHM1234.1

\section{ORCID}

Kalmár T. (1D https://orcid.org/0000-0003-0405-4404

Pieczka I. (D) https://orcid.org/0000-0001-5657-9494

Pongrácz R. iD https://orcid.org/0000-0001-7591-7989 